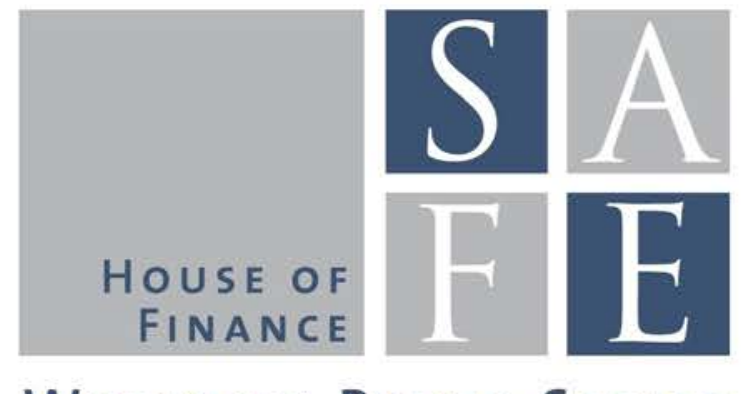

WORKING PAPER SERIES

Yuri Pettinicchi - Nathanael Vellekoop

\title{
Job Loss Expectations, Durable Consumption and Household Finances: Evidence from Linked Survey Data
}

SAFE Working Paper No. 249

SAFE I Sustainable Architecture for Finance in Europe A cooperation of the Center for Financial Studies and Goethe University Frankfurt 


\title{
Job Loss Expectations, Durable Consumption and Household Finances: Evidence from Linked Survey Data* $^{*}$
}

\author{
Yuri Pettinicchi ${ }^{\dagger}$ \\ Max Planck Institute for Social Law and Social Policy \\ Nathanael Vellekoop $¥$ \\ Goethe University Frankfurt and SAFE
}

March 2019

\begin{abstract}
Job security is important for durable consumption and household savings. Using surveys, workers express a probability that they will lose their job in the next 12 months. In order to assess the empirical content of these probabilities, we link survey data to administrative data with labor market outcomes. Workers predict job loss quite well, in particular those whose job loss is followed by unemployment. Workers with higher job loss expectations acquire cheaper cars, and are less likely to buy new cars. In line with models of precautionary saving, higher job loss expectations are associated with more savings and less exposure to risky assets.
\end{abstract}

Keywords: Subjective expectations; Durable consumption; Household saving.

JEL classification: C81, C83, D14, J63

*We gratefully acknowledge research support from the Research Center SAFE, funded by the State of Hessen initiative for research LOEWE. We thank CentERdata for making the survey data of the LISS and the DHS available. Results include our own calculations based on microdata made available by Statistics Netherlands. Part of this research was done while the second author visited the research department of the San Francisco Federal Reserve Bank. Their hospitality is greatly appreciated, and they are not responsible for any of the findings.

†pettinicchi@mea.mpisoc.mpg.de

¥Corresponding author: 3 Theodor W. Adorno-Platz, 60323 Frankfurt am Main, Germany. Email: vellekoop@safe.uni-frankfurt.de 


\section{Introduction}

Expectations of job loss or job insecurity are related to both labor market dynamics and household consumption behavior. With respect to the first, job loss expectations are positively correlated with unemployment and lower levels of wage growth for men (Campbell et al. 2007). With respect to household consumption behavior, standard models of precautionary savings predict that expectations of lower income should affect current savings behavior (Carroll, Dynan and Krane (2003), and see Carroll and Dunn (1997) for the relationship between unemployment expectations and durables).

Job loss expectations are asked in many surveys. A typical question is: "What do you think is the probability that you lose your job in the next 12 months?", where respondents can answer a number in the range of 0-100. Most studies assessing the predictive power of job loss expectations use surveys for both the elicitation of expectations, as well as for the realization. There are three potential problems with this approach. First workers need to answer both wave of a survey to collect a pair of expectation and realization, for which assumptions on the attrition process need to be made. Second, the realization is by construction backward looking. In many surveys there is an issue to what extent the timeframes of the job loss question and the realization overlap. Retrospective questions pose problems with imperfect recall, in particular of short spells of unemployment (Jürges, 2007). When the outcome is binary, which is often the case with realizations, this induces measurement error in the dependent variable that attenuates coefficients of interest (Hausman, Abrevaya and Scott-Morton, 1998; Meyer and Mittag, 2017). Thirdly, respondents might feel stigma or be embarrassed to report an unemployment spell, which induces similar misclassification as the previous point.

Our first contribution is to side-step most of these issues by using administrative data for the outcomes. We link two large household survey datasets with job loss expectations to a monthly worker-firm panel. This linked dataset allows us to to track workers for exactly 12 months after the expectation is elicited, and track transitions within a firm, to another firm, into unemployment, and an 'all other category'. We find that job loss expectations are quite informative for those workers who experience a job loss followed by unemployment, or a job loss followed by a new job to another firm. A second contribution is that we link job loss expectations to durables purchases, in particular car acquisitions. A third contribution is that we look at precautionary savings and the composition of household financial assets. In all three case we exploit the linking of survey data with job loss expectations to administrative data with realizations and economic outcomes.

This paper is related to three strands of literature. The first strand of literature assesses the predictive power of job loss expectations, which is part of a larger literature assessing the predictive power of household expectations (see e.g. Dominitz and Manski (1997); Dominitz (2001) for income expectations.) Stephens Jr (2004); Hendren (2017) both use the Health and Retirement Study for the United States, and find that job loss expectations have some power to predict future job displacement. Hendren (2017) uses this finding to argue that workers have private information about future job loss (see also Curtin (2003)). To the best of our knowledge, we are the first ones to assess the predictive 
power of job loss expectations using administrative data. A second strand of literature relates job loss expectations to outcomes of economic interest, in particular consumption (spending). Stephens Jr (2004) reports some mixed evidence that higher job loss expectations are related to lower food consumption. Klemm (2012) reports mixed evidence for Germany related to household savings. We contribute to this literature by looking at the role of durables (car acquisitions) and savings, both measured in administrative data. A third strand of literature focuses on consumption behavior and financial portfolios of the actual unemployed. Gruber (1997); Hendren (2017) among others report the drop in consumption spending the year prior to actual unemployment using the PSID, and Benito (2006) for the United Kingdom. Browning and Crossley (2009) find that unemployed are more likely to postpone expenditures on smaller durables like clothing. Basten, Fagereng and Telle (2016) use administrative data for Norway and follow a sample of unemployed workers four years before and four years after unemployment. They find some evidence that households increase savings and safe assets the years prior to the realization of unemployment. Our analysis complement this line of research by looking at what workers in the general population expect (and a sub-group of these workers will realize an unemployment spell).

The remainder of this paper is organized as follows. The relevant labor market institutions are described, followed by a description of the survey data and the administrative data (and the linking of the two). Three sets of results are presented. The first set of results shows the predictive power of job loss expectations. The second set of results shows how job loss expectations and car acquisitions are related, and the last set of results focuses on savings behavior and the composition of household portfolios. We end with conclusions.

\section{Institutional Setting}

The data we use is for the Netherlands, a country with around 7 million people in paid employment during the time period used (2010-2016). During these years, the fraction of workers with a flexible contract rose from $21 \%$ in 2010 to $26 \%$ in 2016 . A flexible contract is defined as: a labor contract for a certain time period, or a contract with flexible hours of work, or temp agency work. Employers can offer sequences of flexible contracts, for example a one-year contract followed by another one-year contract, before a labor relationship is considered permanent by labor law. The difference between flexible and permanent labor contracts is the ease with which employers can terminate a contract. Compared to other OECD countries employment protection of permanent labor contracts is higher than the OECD average, and lower than the OECD average for flexible contracts 1 . In an institutional setting with a quarter of employed workers having a flexible labor contract, the concept of job loss is likely to be tied to the probability of renewal of the current labor contract. In the administrative data we are able to track contracts of workers, within the current firm as well as job-movers to a different firm.

\footnotetext{
${ }^{1}$ OECD, online at http://www.oecd.org/employment/emp/oecdindicatorsofemploymentprotection.htm Statistics are for 2013, the last year available.
} 
Regardless whether the worker has a permanent or a flexible contract, all workers are covered under universal unemployment insurance. A government agency evaluates claims to entitlement of unemployment insurance by workers who are laid-off, or whose contract expired. This agency also transfers unemployment benefits. Unemployed workers are not entitled to unemployment benefits in case the worker resigns, or is fired due to wrongful behavior of the employee. The entitlement to unemployment benefits depends on the length of paid work prior to job loss. A worker who has worked for at least 26 weeks out of the 36 weeks prior to unemployment is entitled to three months of unemployment benefits. Another month is added for each year a worker has worked prior to unemployment, e.g. six years of employment history give rise to six months of unemployment benefits. In the first two months of the unemployment spell the replacement rate is $75 \%$ of (average) earnings of the year before the spell started, and $70 \%$ for the remaining months. These are minimum standards: more generous exceptions are possible in case of collective dismissal and in certain collective labor agreements (e.g. public sector workers). One of the conditions for receipt of unemployment benefits is active job search behavior by the unemployed worker. The government agency monitors job search behavior, and can impose sanctions by cutting benefits. The unemployment rate fluctuated between $5.0 \%$ and $7.4 \%$ in the period under study.

\section{$3 \quad$ Data and Empirical Strategy}

We use survey data with expectations of job loss, and link them at the individual level to administrative data provided by Statistics Netherlands.

\subsection{Survey Data}

The survey data are collected on two large (independent) household panel surveys, the Longitudinal Internet Studies for the Social sciences survey (LISS), and the DNB Household Survey (DHS)2 ${ }^{2}$. Both are probabilistic samples and aim to be representative of the Dutch population. The question on job loss expectations in the LISS survey is asked in two modules, an annual core module fielded to everyone participating in the panel, and a quarterly module fielded on a random $50 \%$ subsample. We supplement the LISS core module with observations on job loss expectations from the quarterly module. For those individuals who did not answer the core module in a year, we use the first annual observation from the quarterly module. In both the DHS and the LISS panel the survey question has a similar wording. In the case of LISS: "Do you think that there is any chance that you might lose your job in the coming 12 months? You can indicate this in terms of a percentage." For the DHS: "What do you think is the probability that you lose your job in the next 12 months? You can fill in a number between 0 and 100.". In both panels the question is only asked to those who have a paid job. The left panel of figure 1 shows the

\footnotetext{
${ }^{2}$ The survey data and codebooks in English are freely available for academic research after registration at LISS and DHS.
} 
average job loss expectation for the DHS and the core module of the LISS over time. There are no discernible differences in level or time-profile between the two surveys. After the Great Recession in 2008, there is an increase in job insecurity peaking around the time of the sovereign debt crisis. The subfigure on the right shows the histograms for both surveys, pooled over all years. The pattern is very similar to what Stephens Jr (2004) finds using the Health and Retirement Survey: most people answer $0 \%$ for the probability of losing their job in the next 12 months. Also, the probability of losing a job shows a decreasing pattern, with two exceptions. The answer $50 \%$ stand out, and there is a slight increase at a $100 \%$, this is similar to Stephens Jr (2004).
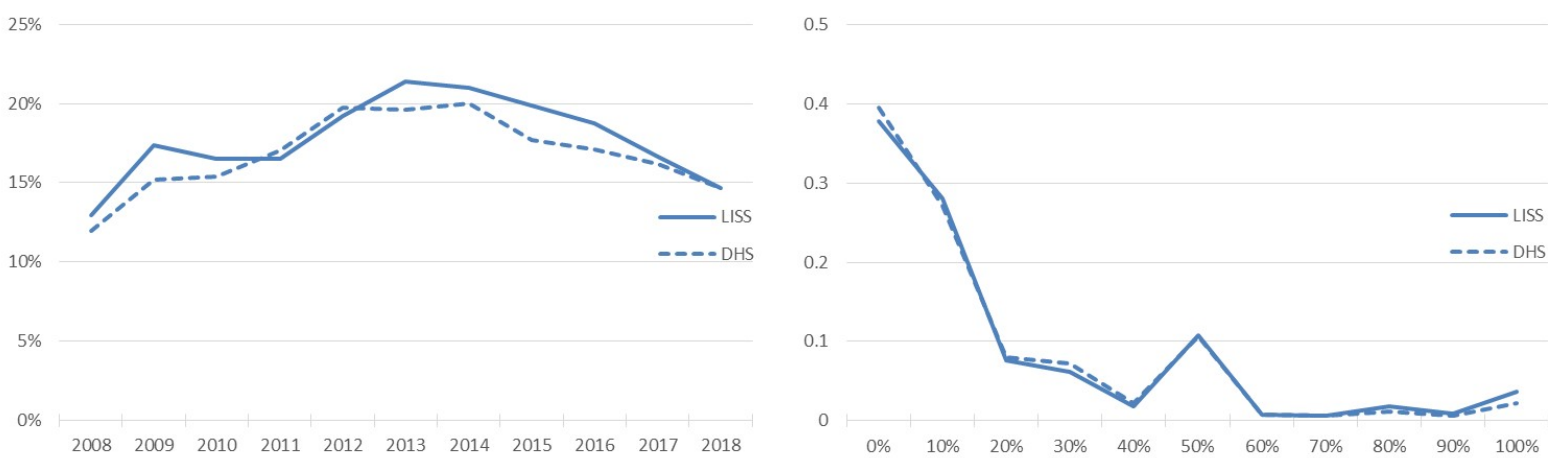

Figure 1: Job Loss Expectations

The figure on the left shows the cross-sectional average of job loss expectations for the core module of the LISS and the DHS in each year. The figure on the right shows the histogram of each survey pooled over all years.

There are two issues worth mentioning. First, the job loss expectation question is typically asked in the middle of the year: mostly June for the LISS, with a reminder in July and mostly April or May for the DHS. In the absence of administrative data, the outcome would typically be measured in the following year by asking retrospective questions. Apart from the issue of imperfect recall, it is very likely that the timeframe of the expectations question does not overlap with the timeframe of the retrospective question. The administrative data allow us to bypass that issue by tracking individuals for exactly 12 months after the job loss expectation is elicited. A second issue of importance is the wording of the question: the question is framed in terms of losing a job, not necessarily the probability of becoming unemployed. The question of how a job is defined is deferred to the subsection on administrative data, but expecting to lose a job allows for several labor market transitions. Though it would be of interest to see whether the expected job loss is voluntary or not, we have little information in the survey to distinguish these two states. Manski and Straub (2000) use an additional question to the Survey of Economic Expectations to distinguish voluntary and involuntary job separations. We use the administrative data to look at several possible transitions: a new job in the same firm, a new job in a different firm, unemployment, and all other outflows after losing the current job. 


\subsection{Administrative Data}

The main administrative data we use is an integral worker-firm dataset containing monthly wages and contract information. The data is collected by firms and used to calculate the length and level of unemployment benefits by the government agency that pays out unemployment benefits, see Subsection 2. Since all workers (including workers in the public sector) are covered by unemployment insurance, the data is comprehensive for all (legal) employment. All workers and firms are anonymized, and Statistics Netherlands provides identifiers to track workers and firms over time, as well as to be able to link them to other datasets with person and household information. In addition to the worker-firm data we use a dataset with income sources an individual has in each month. A drawback of the data is that we do not observe occupations. We therefore define a job as a contract with a firm, and we observe the start and end date of the contract. We track individuals in the 12 months after the job loss expectation is elicited, and construct five possible outcomes: (1) continuation in the same contract (by construction with the same firm); (2) a different contract with the same firm; (3) a different contract with a different firm; (4) unemployment, as measured by termination of the contract and receiving unemployment benefits; (5) termination of the contract and any other non-employment. The last category consists mainly of social assistance, disability insurance, or no income. Households who are self-employed or retired are excluded from the regression sample. As mentioned in Section 2 , a requirement for receiving unemployment benefits is to be available for the labor market and to actively search and apply for jobs.

In addition, two other administrative datasets are used for economic outcomes. We link the integral car registration and data on household wealth. The car registration records the start and end date of ownership of a car. The transfer of ownership matters for purposes of vehicle insurance (which is mandatory), the administrative records are therefore likely to have large and accurate coverage. However, changes in title do not necessarily reflect transactions: when cars are passed on within a family or gifted, these changes will be reflected in the dependent variable. Changes within a household are few, and we include them in the analysis. In the data new and used (second-hand) cars can be distinguished. Also the import value (almost all cars in the Netherlands are imported) is recorded, which is the value of a car without accessories or modifications by the car dealer. Also, dealer discounts and administrative levies are not included, so for new cars there is likely to be a difference between the price the consumer pays and the car value. $3^{3}$ For all cars for which we observe the import value, we adjust the value using the age of the car and a depreciation schedule that the Dutch Tax Authority uses to estimate the value of vehicles (which is close to exponential). All cars with missing values for the imputed value are included in the analysis with value zero.

The second data source consists of integral household assets and liabilities (Crossley et al. (2017) link some other questions of the LISS survey to the years 2007-2009 of this dataset). The data is provided to Statistics Netherlands by the Dutch Tax Authority (house value, stocks and bonds, outstanding mortgage loans and considerable capital provision to

\footnotetext{
${ }^{3}$ We do not have any data on the financing of cars, e.g. car loans or payment plans.
} 
companies) and banks (the sum of all checking and savings accounts). All values are provided at the end of the calendar year and aggregated at the level of the household. For the empirical analysis this means that we can only match a half to two-thirds of the timeframe of 12 months after job loss expectations are elicited. From asset levels we construct savings flows by taking the first difference. Net worth is used as a control variable in all regressions with economic outcomes, and savings, stocks and financial wealth are used as outcomes in the last part of the analysis.

\subsection{Linking}

We link both the DHS and the LISS data surveys at the person level to the administrative datasets. Statistics Netherlands provides the environment to work with both types of data, and ensures anonymity of individuals and firms in all published results. Respondents in the DHS and the LISS are asked for consent to be linked, and consent rates are high (around $85 \%$ of persons with job loss expectations for both the DHS and the LISS). The dataset used in regressions spans the years 2010-2015 for the LISS and 2010-2016 for the DHS. Table 1 presents the summary statistics of the pooled DHS and LISS data. The regression sample contains a little less than 20,000 job loss expectations for around 6,000 households. On average workers expect to lose their job in the next 12 months with 17.7 percent chance, though the underlying distribution is quite skewed (see Figure 1). When workers are tracked in the 12 months following the job loss elicitation, the average job loss probability (defined as a termination of the contract) is with $21.9 \%$ a little larger than the average job loss expectation in the sample. Looking at the four subcategories, we find that about half transition into another job without an unemployment spell. One third of this group $(3.8 \%$ out of $10.5 \%)$ continue within the same firm. $4^{4}$ and two-thirds moves to a different company. The other half experiences an interruption, with a third (3.8\% out of $11.3 \%)$ receiving unemployment benefits. The remainder category of "Other job loss" is quite sizable (a third of the total group of workers experiencing a loss of the current job contract) and consists of unemployed not receiving or not entitled to unemployment benefits, and receivers of disability insurance and social assistance. The regression sample does not contain any retired or self-employed, which could potentially be two other transitions after losing a job.

\subsection{Empirical Strategy}

In order to evaluate the empirical content of job loss expectations, we follow individuals during the 12 months after expectations are elicited. We allow for four possible transitions

\footnotetext{
${ }^{4}$ Here it is useful to point out that there might be a difference how a respondent understands the concept of a job when answering the expectation question, and how we define jobs by using contracts. If a respondent thinks of a continuation in the same job with a different contract as not losing a job, we would erroneously classify this transition as a job loss. In the regressions we therefore separate by subcategory as well. Incidentally, would this entire category not be classified as job loss, then the average job loss expectation is quite close to the realization ( $17.7 \%$ and $18.1 \%$ respectively).
} 
Table 1: Summary Statistics

\begin{tabular}{lrr}
\hline & Mean & St. Dev. \\
\hline Job loss expectation [0-100] & 17.727 & 24.481 \\
& & \\
Any job loss $(0 / 1)$ & 0.219 & 0.414 \\
New job, same firm $(0 / 1)$ & 0.038 & 0.192 \\
New job, new firm $(0 / 1)$ & 0.067 & 0.251 \\
Unemployed (0/1) & 0.038 & 0.191 \\
Other job loss (0/1) & 0.076 & 0.265 \\
& & \\
College $(0 / 1)$ & 0.233 & 0.423 \\
Partner (0/1) & 0.768 & 0.422 \\
Female & 0.484 & 0.500 \\
Age 30 and younger & 0.129 & 0.335 \\
Age 31-40 & 0.261 & 0.439 \\
Age 41-50 & 0.277 & 0.448 \\
Age 51-60 & 0.267 & 0.442 \\
Age 61 and older & 0.066 & 0.248 \\
Very high urbanization & 0.176 & 0.381 \\
High urbanization & 0.296 & 0.456 \\
Moderate urbanization & 0.213 & 0.409 \\
Low urbanization & 0.213 & 0.410 \\
Very low urbanization & 0.102 & 0.302 \\
Family size & 2.805 & 1.289 \\
House-owner & 0.811 & 0.392 \\
Annual wage income & 40,005 & 25,552 \\
Disposable household income & 27,331 & 11,981 \\
Net worth & 66,649 & 136,144 \\
& & \\
N observations & 19,670 & \\
N households & 6,151 & \\
\hline
\end{tabular}

Summary statistics for the regression sample. Disposable household income and net worth are deflated Euro values. 
within this window of 12 months, and the baseline is keeping a job. Starting with the month of job loss expectation, the first transition out of a job is recorded. There are three reasons why respondents would potentially not report some of these transitions with retrospective questions. Some of these transitions would be missed if the timeframe of the retrospective question does not overlap with the 12 months of the job loss expectation. Furthermore, short spells of not having a job, or spells farther back in the past might not be reported, or not reported correctly (Jürges (2007) finds evidence for under-reporting and misreporting in German survey data). Thirdly, there might be an element of stigma or shame associated with being out of a job, increasing the chances of misreporting. Due to the binary nature of the dependent variable, misclassification of the transition status induces attenuation in the estimated coefficients (Hausman, Abrevaya and Scott-Morton, 1998; Meyer and Mittag, 2017). Here we expect administrative data could increase the predictive accuracy of job loss expectations. We estimate Probit models for each of the four transitions separately, and a model for any of the four transitions. Marginal effects are averaged over the regression sample.

A similar issue of misclassification could arise in the context of car acquisitions. For example, car purchases in a year could be measured as the difference between number of cars owned at the beginning and at the end of the year. In this example, any car purchase combined with a sale within the year would be missed, regardless of whether it is the sale of an old car combined with the purchase of a new vehicle, or a purchase and sale of the same car within the year. Linking survey data to the car registry allows us to track changes in car acquisition within the window of 12 months. Probit models are estimated on the probability of acquiring a car in the next 12 months, as well as acquiring a new or a second hand car. We include time in months since the last car acquisition as an independent variable, and set this variable to zero for first-time vehicle-owners. For the value of the car the import value times imputed depreciation is used, and missing values for both car owners and non-car owners are replaced with the value of zero. We estimate Tobit models on the $\log$ of $(1+$ imputed value). An alternative would be to estimate Heckman style regressions, but it is not clear which variable would be suitable as an exclusion restriction.

With respect to savings flows and asset levels our interest is in the allocation of safe and risky assets. We use combined balances of savings and checking accounts as a measure for safe assets (we cannot distinguish between the two), and combined balances for bond and stock holdings and mutual funds as a measure for risky assets. Though bond holdings are typically not considered to be risky assets, we cannot distinguish between stock and bond holdings in the data, and only a small fraction of the Dutch population holds bonds. Unfortunately in the case of savings and assets, we cannot align the timeframe of job loss expectations to the full 12 months of realizations. Assets are measured at the end of the calendar year, which is in between six and eight months after job loss expectations are elicited for most respondents in the sample. For savings we take the difference of asset levels at the end of the year and the beginning of the year, so savings flows have the same issue. We censor asset levels at percentile 97.5 and savings flows percentiles 5 and 95 . Since assets are measured at the household level (data are aggregated over all household members), the job loss expectation of the main earner in the household is used. The main 
earner is defined by average wage income in the 12 months prior to the elicitation of the job loss expectation.

\section{Empirical Results}

We report three sets of empirical results. First we show the relationship between job loss expectations and realizations in the next 12 months. The second set of results pertains to job loss expectations and car acquisitions, as well as whether the acquired car is new or second-hand. The last set of results shows how job loss expectations affect changes in savings flows and the composition of financial balance sheets of households.
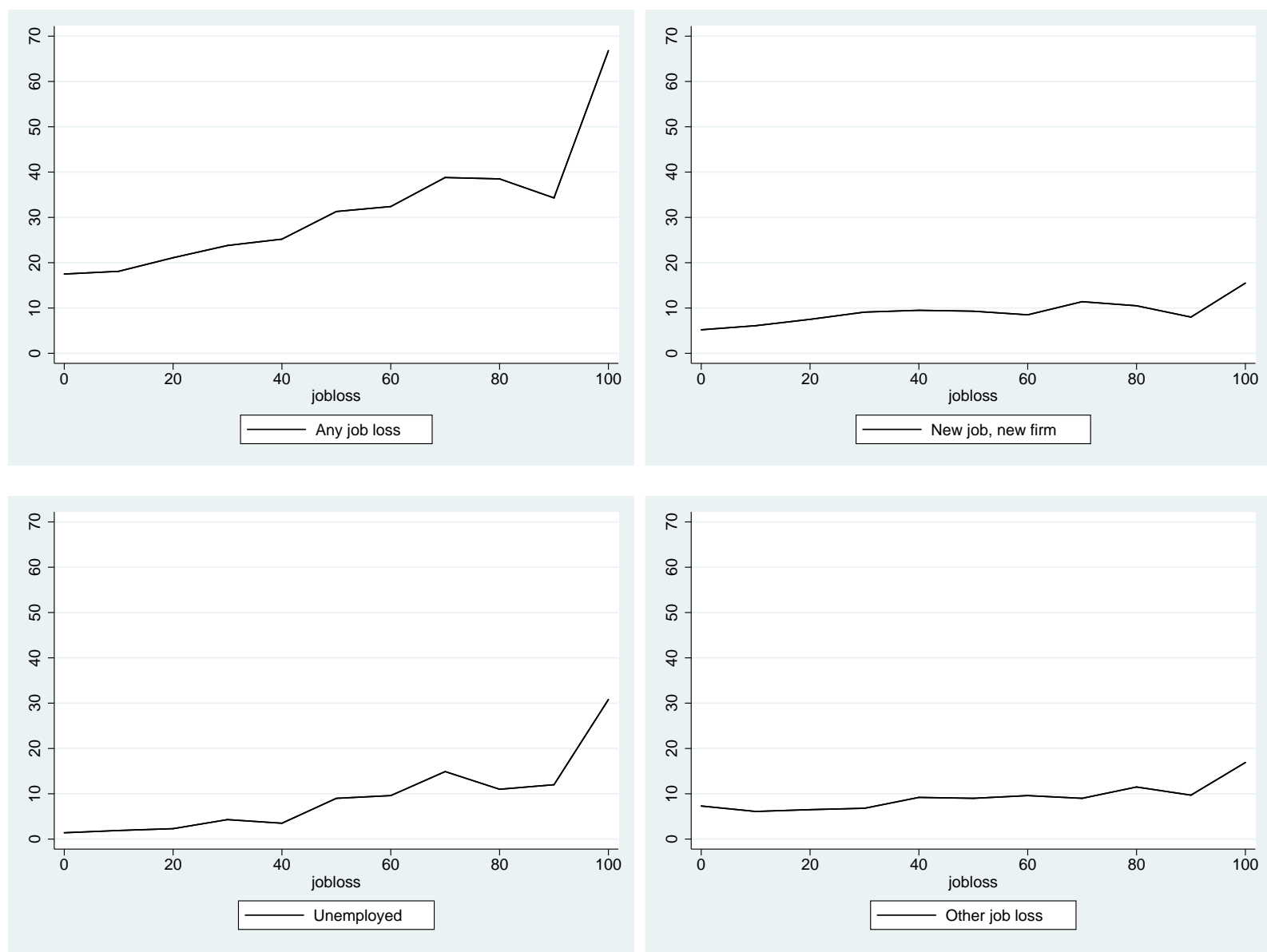

Figure 2: Job Loss Expectations and Realizations

The top left figure shows realizations of any job loss within the 12 months after job loss expectations are elicited in the LISS and DHS surveys. The sample is based on the linked survey data. The other figures show the three main transitions after losing a job: a new job in a different firm, unemployment (measured by receiving unemployment benefits), and the category 'any other job loss'. We have to suppress the group (new job, same firm) for disclosure reasons. 


\subsection{Predictive Power}

In Figure 2 two subfigures show the unconditional distribution of job loss expectations in 11 brackets (horizontal axis) and realizations. The subfigure on the left shows the probability of any job loss, the subfigure on the right plots three of the four categories of job loss.$^{5}$ In both figures-any job loss on the left and the three subcategories on the right- the realization of job loss is increasing the expectation, though far from being on the 45-degree line. Zooming into the three subcategories reveals an interesting pattern. Workers who have a transition into unemployment have a much steeper profile of expecting to lose a job. Workers who transition into a new job in a new firm (without any unemployment spell) have a much flatter slope. In fact, the slope is very similar to workers who transition into the 'Other job loss' category. The overall pattern of job loss realizations and expectations seems mainly driven by workers expecting a transition from work into unemployment. Stephens Jr (2004) and Hendren (2017) report similar patterns for the HRS in the United States, though the slope is less steep.

Table 2 shows marginal effects after Probit estimations, averaged over the regression sample. In column (1), there is a positive and statistically significant correlation between job loss expectations and the probability to lose a job. A one percentage point increase in job loss expectations is associated with a 0.89 percentage point increase in the probability to lose a job, which is slightly less than one-for-one. This is after controlling for demographics, regional unemployment, time (year-month) and industry fixed effects. Standard errors are clustered at the individual level. Results are robust to using linear probability models, or selecting only the main earner in the household. Looking at columns (2)-(5), we find that on average workers predict the loss of their current job quite well, with the exception of the transition to a new job (contract) within the same firm (column (2)). In line with the unconditional realizations in Figure 2, workers with a transition into unemployment (with benefits) have the best prediction, followed by firm-movers and any other job loss. For workers transitioning into unemployment, a one percentage point increase in job loss expectations is associated with a 1.46 percentage point increase in the probability to become unemployed (column (4)), which is more than one-for-one (though the pattern is not entirely linear, as we will show later).

Comparing columns (2)-(5), it is debatable whether the stayers within the firm (column (2)) can be classified as a job loss. The marginal effect of job loss expectations is quite small, and not statistically significant. Also few of the other covariates are associated with predicting this particular outcome. An argument for including this category in the analysis is that many larger firms can be characterized by internal labor markets. An argument against including might be that in this particular outcome we cannot distinguish well jobs from contracts (e.g. a worker might continue a job with an improved contract). Despite these shortcoming, we include this category in the remainder of the analysis. Looking at the other columns, there are interesting patterns to observe in the covariates, that either appear, or average out in the overall job loss category in column (1). For example, there

\footnotetext{
${ }^{5}$ The fourth category, new job at the same firm, is suppressed because the number of observations in some, but not all brackets is too low to be disclosed.
} 
is a U-shaped pattern in age groups for workers who move to another firm and for workers moving into the 'other job loss' category. The reverse pattern is visible for workers transitioning into unemployment after job loss. A potential explanation is that older workers face more barriers in moving to another firm, and are more likely to be eligible for unemployment benefits due to their employment history ${ }^{6}$ Also workers with a higher wage income in the current job are more likely to transition into a new job at another firm, whereas they are less likely to transition into unemployment or 'Other job loss'. However, the latter two groups affect the overall job loss probability in column (1).

In Figure 3 marginal effects are reported of Probit regressions with job loss expectations in 11 brackets. The Probit regressions are otherwise similar to the regressions reported in Table 2. The job loss expectation of $0 \%$ is the reference category. The top figure shows a pattern similar to the unconditional results in Figure 2; job loss realizations are increasing in job loss expectations, though not monotonically. There is a marked increase for the bracket containing the $100 \%$ job loss expectations.7 Focusing on the four subfigures we find that job loss expectations are not predictive of within-firm transitions, and only very little of the category 'Other job loss'. In the latter only the bracket $100 \%$ is statistically significant at $5 \%$, and bracket $80 \%$ at $10 \%$. The average effect in Table 2, column (5) is likely driven by the larger job loss expectations $(50-100 \%){ }^{8}$ The profile for firm-movers (right subfigure in the middle) is moderately increasing, with flatter regions in the middle of the distribution. The subfigure for the transition into unemployment shows a clear increasing pattern, with relatively tight $95 \%$ confidence intervals.

Overall we conclude that job loss expectations are quite predictive for those workers who lose their job followed by a transition into unemployment, and moderately predictive of firm-movers. These findings corroborate with Stephens Jr (2004) for displaced workers? though we find that job loss expectations are also predictive for job leavers. With respect to all four subcategories, we cannot distinguish between voluntary and involuntary job separations, perhaps with the exception of the category of unemployed. In order to be entitled to unemployment benefits, job separation has to be involuntary (or the end of a temporary contract without renewal). The distinction between voluntary and involuntary job separation is important for the analysis of labor market dynamics. However, without other information, e.g. follow-up questions in the spirit of Manski and Straub (2000), we cannot investigate this particular matter further.

\footnotetext{
${ }^{6}$ Note that workers who retire in the next 12 months after job loss expectations are excluded from the estimation sample.

${ }^{7}$ In fact, taken literally the interpretation would be that workers who answer a job loss of a $100 \%$ have a probability larger than one to lose their job. Here the approximation around the bracket of a $100 \%$ is clearly an approximation. The same phenomenon happens in the left subfigure on the bottom row, showing the transition into unemployment.

${ }^{8}$ It is not inconceivable that the 'Other job loss' category contains some heterogeneous subgroups that we fail to identify in the administrative data. If true, it could be that the average effect for this category masks some clearer patterns by subgroups.

${ }^{9}$ Compare the subfigure for unemployed to his Figure 3A, p. 259
} 
Table 2: Predictive Power of Job Loss Expectations

\begin{tabular}{|c|c|c|c|c|c|}
\hline & $\begin{array}{l}\text { Lost Job } \\
\text { (1) }\end{array}$ & $\begin{array}{c}\text { New Job, Same Firm } \\
(2)\end{array}$ & $\begin{array}{c}\text { New Job, New Firm } \\
(3)\end{array}$ & $\begin{array}{c}\text { Unemployed } \\
(4)\end{array}$ & $\begin{array}{c}\text { Other Job Loss } \\
(5)\end{array}$ \\
\hline Job loss expectation [0-100] & $\begin{array}{l}0.0089^{* * *} \\
(0.000)\end{array}$ & $\begin{array}{c}0.0005 \\
(0.001)\end{array}$ & $\begin{array}{l}0.0054^{* * *} \\
(0.001)\end{array}$ & $\begin{array}{l}0.0146^{* * *} \\
(0.001)\end{array}$ & $\begin{array}{l}0.0021^{* * *} \\
(0.001)\end{array}$ \\
\hline College education & $\begin{array}{l}0.0769^{* *} \\
(0.038)\end{array}$ & $\begin{array}{r}-0.0489 \\
(0.050)\end{array}$ & $\begin{array}{l}0.1312^{* * *} \\
(0.041)\end{array}$ & $\begin{array}{c}0.0209 \\
(0.073)\end{array}$ & $\begin{array}{c}-0.0859 \\
(0.067)\end{array}$ \\
\hline Partner in household & $\begin{array}{c}-0.0746^{*} \\
(0.039)\end{array}$ & $\begin{array}{r}0.0817 \\
(0.050)\end{array}$ & $\begin{array}{c}0.0176 \\
(0.045)\end{array}$ & $\begin{array}{c}-0.0764 \\
(0.069)\end{array}$ & $\begin{array}{c}-0.1436^{* *} \\
(0.057)\end{array}$ \\
\hline Female & $\begin{array}{l}-0.2377^{* * *} \\
(0.035)\end{array}$ & $\begin{array}{r}0.0096 \\
(0.043)\end{array}$ & $\begin{array}{r}-0.0050 \\
(0.036)\end{array}$ & $\begin{array}{l}-0.1643^{* * *} \\
(0.062)\end{array}$ & $\begin{array}{l}-0.3110^{* * *} \\
(0.058)\end{array}$ \\
\hline Age $31-40$ & $\begin{array}{l}-0.3346^{* * *} \\
(0.043)\end{array}$ & $\begin{array}{r}0.0243 \\
(0.063)\end{array}$ & $\begin{array}{l}-0.1812^{* * *} \\
(0.047)\end{array}$ & $\begin{array}{l}0.1420^{*} \\
(0.078)\end{array}$ & $\begin{array}{l}-0.4840^{* * *} \\
(0.062)\end{array}$ \\
\hline Age 41-50 & $\begin{array}{l}-0.4571^{* * *} \\
(0.045)\end{array}$ & $\begin{array}{c}0.0478 \\
(0.064)\end{array}$ & $\begin{array}{l}-0.3329^{* * *} \\
(0.050)\end{array}$ & $\begin{array}{r}0.1069 \\
(0.082)\end{array}$ & $\begin{array}{l}-0.6039^{* * *} \\
(0.067)\end{array}$ \\
\hline Age 51-60 & $\begin{array}{l}-0.4932^{* * *} \\
(0.046)\end{array}$ & $\begin{array}{c}0.0324 \\
(0.065)\end{array}$ & $\begin{array}{l}-0.5263^{* * *} \\
(0.052)\end{array}$ & $\begin{array}{l}0.1914^{* *} \\
(0.084)\end{array}$ & $\begin{array}{l}-0.5589^{* * *} \\
(0.067)\end{array}$ \\
\hline Age 61 and older & $\begin{array}{l}-0.3619^{* * *} \\
(0.064)\end{array}$ & $\begin{array}{c}0.0675 \\
(0.086)\end{array}$ & $\begin{array}{l}-0.4360^{* * *} \\
(0.079)\end{array}$ & $\begin{array}{c}0.1783 \\
(0.120)\end{array}$ & $\begin{array}{l}-0.3727^{* * *} \\
(0.093)\end{array}$ \\
\hline High urbanization & $\begin{array}{c}0.0016 \\
(0.048)\end{array}$ & $\begin{array}{l}0.1261^{* *} \\
(0.061)\end{array}$ & $\begin{array}{c}-0.0272 \\
(0.053)\end{array}$ & $\begin{array}{c}0.0014 \\
(0.083)\end{array}$ & $\begin{array}{c}-0.0359 \\
(0.077)\end{array}$ \\
\hline Moderate urbanization & $\begin{array}{r}0.0408 \\
(0.051)\end{array}$ & $\begin{array}{l}0.1450^{* *} \\
(0.066)\end{array}$ & $\begin{array}{c}0.0245 \\
(0.057)\end{array}$ & $\begin{array}{c}0.0563 \\
(0.088)\end{array}$ & $\begin{array}{c}-0.0492 \\
(0.082)\end{array}$ \\
\hline Low urbanization & $\begin{array}{r}-0.0573 \\
(0.052)\end{array}$ & $\begin{array}{c}0.0559 \\
(0.067)\end{array}$ & $\begin{array}{r}-0.0021 \\
(0.058)\end{array}$ & $\begin{array}{c}-0.0424 \\
(0.089)\end{array}$ & $\begin{array}{r}-0.1161 \\
(0.081)\end{array}$ \\
\hline Very low urbanization & $\begin{array}{r}-0.0586 \\
(0.060)\end{array}$ & $\begin{array}{c}0.0326 \\
(0.076)\end{array}$ & $\begin{array}{c}-0.0483 \\
(0.066)\end{array}$ & $\begin{array}{c}0.0502 \\
(0.104)\end{array}$ & $\begin{array}{c}-0.0900 \\
(0.092)\end{array}$ \\
\hline Number of household members & $\begin{array}{c}-0.0259^{*} \\
(0.013)\end{array}$ & $\begin{array}{c}-0.0320^{*} \\
(0.017)\end{array}$ & $\begin{array}{c}-0.0085 \\
(0.016)\end{array}$ & $\begin{array}{c}-0.0188 \\
(0.024)\end{array}$ & $\begin{array}{c}-0.0303 \\
(0.020)\end{array}$ \\
\hline Main earner in household & $\begin{array}{r}-0.0017 \\
(0.029)\end{array}$ & $\begin{array}{c}0.0013 \\
(0.042)\end{array}$ & $\begin{array}{r}0.0427 \\
(0.034)\end{array}$ & $\begin{array}{r}-0.0435 \\
(0.049)\end{array}$ & $\begin{array}{c}-0.0140 \\
(0.043)\end{array}$ \\
\hline Log(annual wages) & $\begin{array}{c}-0.4552^{* * *} \\
(0.030)\end{array}$ & $\begin{array}{r}-0.0471 \\
(0.036)\end{array}$ & $\begin{array}{l}0.1006^{* * *} \\
(0.034)\end{array}$ & $\begin{array}{c}-0.4120^{* * *} \\
(0.043)\end{array}$ & $\begin{array}{c}-0.6259^{* * *} \\
(0.042)\end{array}$ \\
\hline Local unemployment & $\begin{array}{c}0.0114 \\
(0.015)\end{array}$ & $\begin{array}{c}-0.0193 \\
(0.019)\end{array}$ & $\begin{array}{r}-0.0009 \\
(0.017)\end{array}$ & $\begin{array}{r}-0.0040 \\
(0.026)\end{array}$ & $\begin{array}{l}0.0454^{*} \\
(0.024)\end{array}$ \\
\hline p-value industry & 0.000 & 0.001 & 0.000 & 0.000 & 0.000 \\
\hline Mean dependent variable & 0.220 & 0.039 & 0.068 & 0.039 & 0.078 \\
\hline $\mathrm{N}$ households & 6,140 & 6,029 & 6,089 & 5,983 & 6,048 \\
\hline $\mathrm{N}$ observations & 19,628 & 19,163 & 19,461 & 19,003 & 19,217 \\
\hline
\end{tabular}

All models are estimated with Probit, and include a full set of 2-digit industry dummies, time fixed effects and controls for the survey used. Marginal effects averaged over the sample are reported. Outcomes are measured in the 12 months after the job loss expectations are elicited. The reference category for age is 'Age 30 and younger', and 'Very high urbanization' for area density. Robust standard errors (in parentheses) are clustered at the individual level. */**/*** correspond to $10 \% / 5 \% / 1 \%$ significance level. 

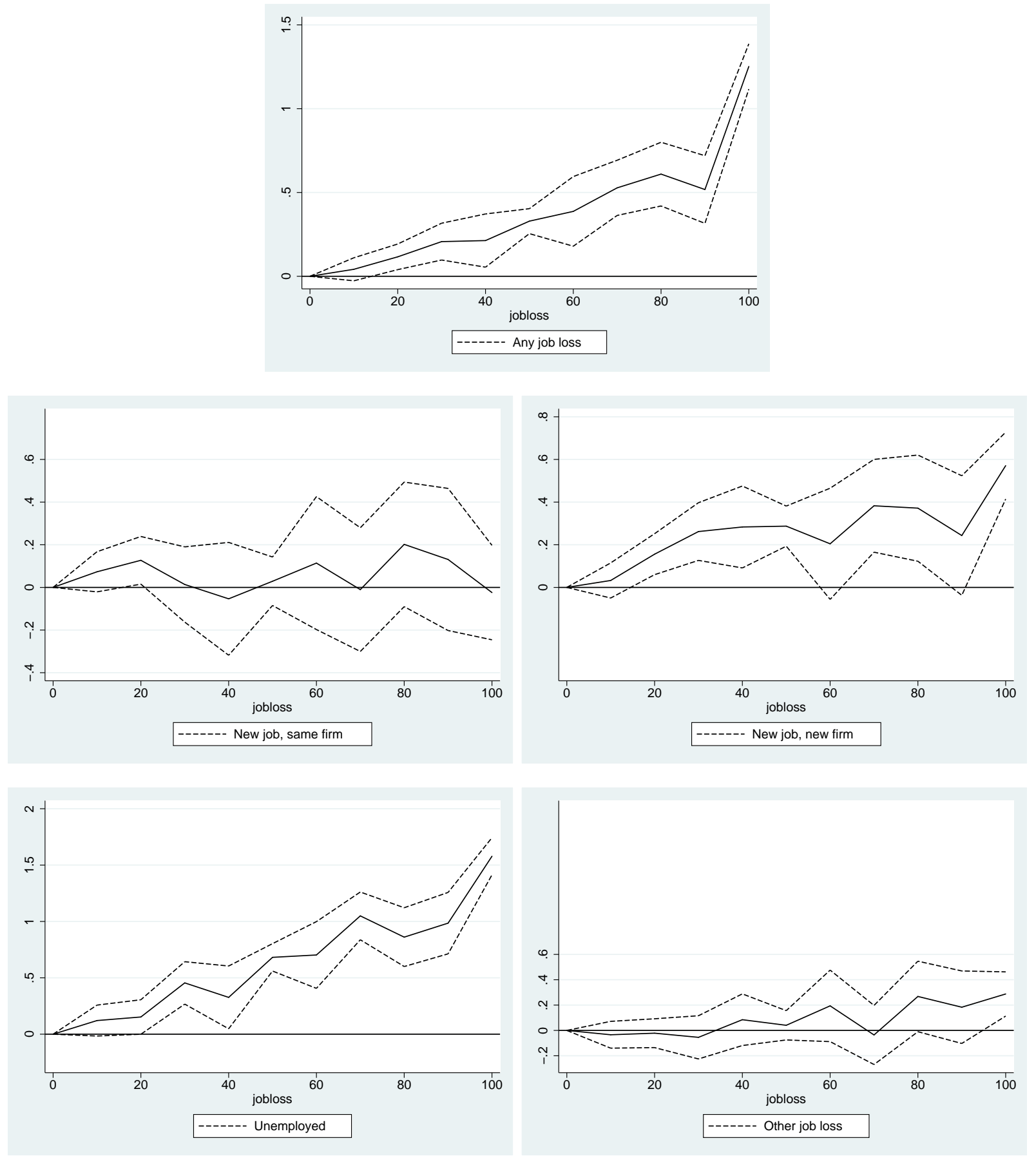

Figure 3: Job Loss Expectations and Realizations

Marginal effects of job loss expectations in 11 bins (solid lines) and $95 \%$ confidence intervals (dashed lines) from Probit regressions. The same set of controls is used as in Table 2 The top figure shows realizations of any job loss within the 12 months after job loss expectations are elicited in the LISS and DHS surveys. The figures in the middle show transitions within firm and to another firm. The figures at the bottom show transitions into unemployment (with benefits), and any other transition after job loss (mainly social assistance and Disability Insurance. Retirement and self-employed are excluded from the sample). 


\subsection{Car Acquisitions}

After having established the empirical content of job loss expectations, we turn to the relationship between expectations and outcomes of economic interest. In Table 3 we report the results on both the extensive and the intensive margin of car acquisitions and job loss expectations. The odd columns report marginal effects averaged over the regression sample after Probit regressions. The even columns report point coefficients of Tobit regressions. All columns control for net worth of the household (using the inverse hyperbolic sine transformation to account for negative and zero values) and time since the last acquisition of a car (in months). Around 10.5 percent of individuals in the sample acquire a car in the 12 months after job loss expectations. In columns (1) and (3) there is no relationship to discern between job loss expectations and the probability to acquire a car. The marginal effect is small and standard errors are large. In columns (2) and (4) we find a negative relationship with (imputed) car value. The relationship is small: a one percentage point increase in job loss expectations is associated with approximately 0.188 percent lower car value, conditional on acquiring. ${ }^{10}$.

Before looking separately into new and second-hand cars acquisitions, it is worthwhile to consider the role of expectation errors, in a similar fashion to Stephens Jr (2004). We construct the expectation error by subtracting the realization from the job loss expectations. The interpretation is that workers with positive expectation errors had a non-zero job loss expectations and no job loss in the 12 months after the expectation. Workers with negative expectation errors had a job loss expectation lower than a 100\%, and a job separation in the 12 months after. For the realization of job separations we use the overall category of any job loss. From the analysis in subsection 4.1 it is clear that realizations of job separations are heterogeneous in terms of observable characteristics. In order to avoid substitutable pathways due to unobservable factors, we use the earlier finding that on average job loss expectations are predictive of three out of four transitions, and the fourth category is small. The overall category of any job loss is used in the analysis of expectation errors. Turning to columns (5) and (6), we find that expectation errors are negatively associated with acquiring a car in the next 12 months, as well as with a lower car value. A one percentage point increase in the expectation error is associated with a 0.067 percentage point decrease in the probability of acquiring a car, and a 0.11 percent lower car value. When we split the expectation errors in positive and negative values, we find an asymmetric response. In column (7) it is the negative expectation errors that drive the result in column (5). A one percentage point increase of negative error values is associated with a 0.084 percentage point decline ${ }^{11}$ in the probability of acquiring a car. This is the group of workers whose job loss expectations ex post were too low, but who still had a correct anticipation by being less likely to acquire a car. The group of workers with positive error values is also less likely to buy a car, but is not statistically significant.

\footnotetext{
${ }^{10} \mathrm{Job}$ loss expectations in the table are divided by a 100 to increase readability. This statistic uses the rule-of-thumb approximation for Tobit, multiplying the point coefficient with the fraction of uncensored observations: $0.105 \times 1.793 \approx 0.188$.

${ }^{11}$ Negative error values are multiplied with -1 to facilitate interpretation.
} 
Table 3: Job Loss Expectations and Car Purchases

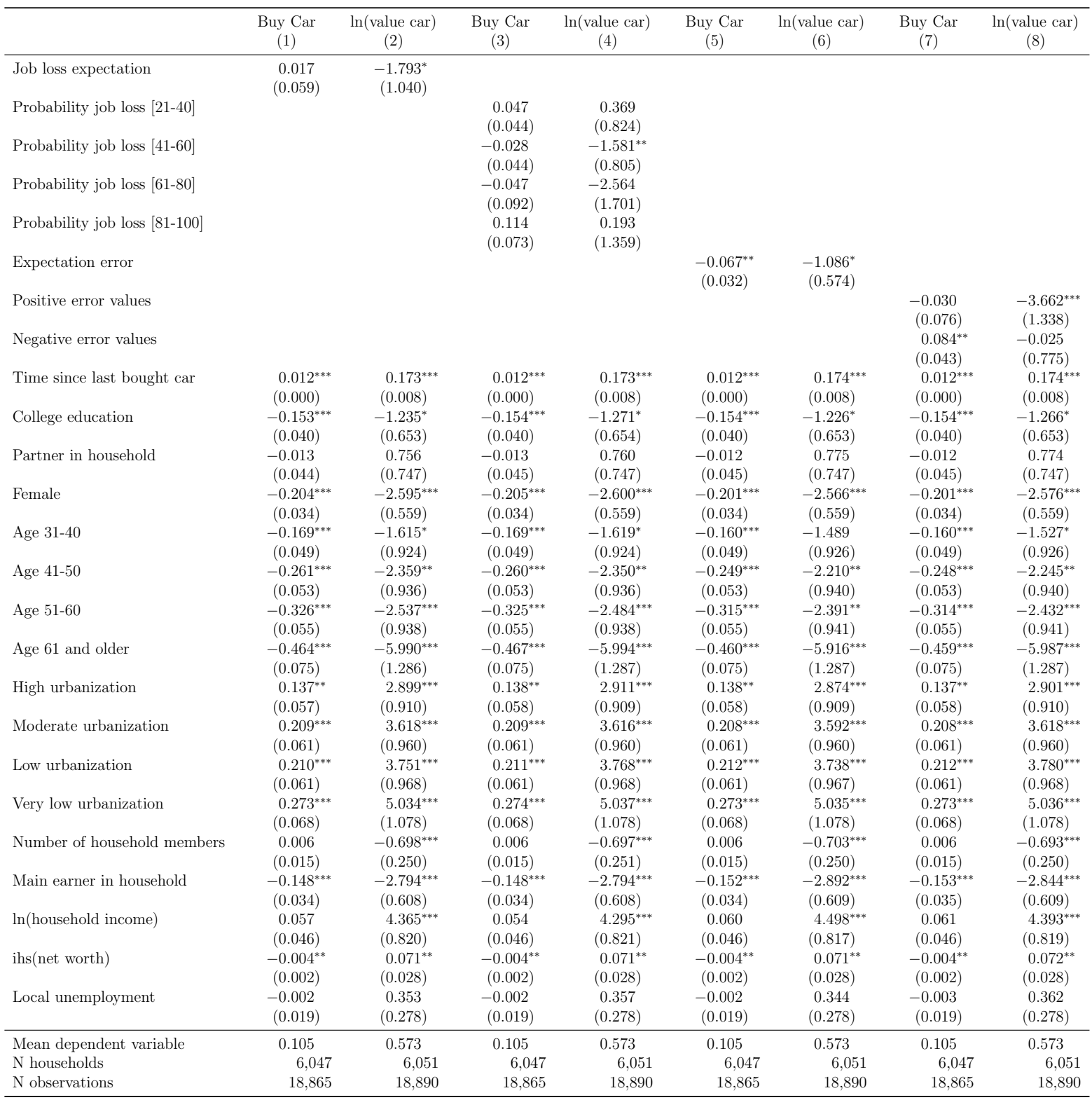

Models in odd columns are estimated with Probit, marginal effects averaged over the sample reported. Models in even columns are estimated with Tobit, point coefficients reported. All models include a set of time fixed effects and dummies for the survey used. Outcomes are measured in the 12 months after the job loss expectations are elicited. The reference category for age is 'Age 30 and younger', 'Very high urbanization' for area density, and 'Probability job loss [0-20]' for the job loss expectations. Variables 'Job loss expectation', 'Expectation error', 'Positive error values', and 'Negative error values' are divided by a 100 to increase readability. In addition, 'Negative error values' are transformed to take on values on the positive range.

*/**/*** correspond to $10 \% / 5 \% / 1 \%$ significance level. 
Table 4: Job Loss Expectations and Type of Car Purchase

\begin{tabular}{|c|c|c|c|c|c|c|c|c|}
\hline & $\begin{array}{l}\text { Old Car } \\
\text { (1) }\end{array}$ & $\begin{array}{c}\text { New Car } \\
\text { (2) }\end{array}$ & $\begin{array}{c}\text { Old Car } \\
\text { (3) }\end{array}$ & $\begin{array}{c}\text { New Car } \\
\text { (4) }\end{array}$ & $\begin{array}{c}\text { Old Car } \\
\text { (5) }\end{array}$ & $\begin{array}{c}\text { New Car } \\
(6)\end{array}$ & $\begin{array}{l}\text { Old Car } \\
\text { (7) }\end{array}$ & $\begin{array}{c}\text { New Car } \\
\text { (8) }\end{array}$ \\
\hline Job loss expectation & $\begin{array}{c}0.095 \\
(0.061)\end{array}$ & $\begin{array}{c}-0.283^{* *} \\
(0.113)\end{array}$ & & & & & & \\
\hline Probability job loss [21-40] & & & $\begin{array}{c}0.071 \\
(0.047)\end{array}$ & $\begin{array}{c}-0.062 \\
(0.084)\end{array}$ & & & & \\
\hline Probability job loss [41-60] & & & $\begin{array}{c}0.028 \\
(0.044)\end{array}$ & $\begin{array}{c}-0.254^{* *} \\
(0.099)\end{array}$ & & & & \\
\hline Probability job loss [61-80] & & & $\begin{array}{c}0.009 \\
(0.097)\end{array}$ & $\begin{array}{c}-0.219 \\
(0.176)\end{array}$ & & & & \\
\hline Probability job loss [81-100] & & & $\begin{array}{c}0.170^{* *} \\
(0.076)\end{array}$ & $\begin{array}{c}-0.147 \\
(0.143)\end{array}$ & & & & \\
\hline Expectation error & & & & & $\begin{array}{c}-0.050 \\
(0.034)\end{array}$ & $\begin{array}{c}-0.067 \\
(0.056)\end{array}$ & & \\
\hline Positive error values & & & & & & & $\begin{array}{c}0.037 \\
(0.080)\end{array}$ & $\begin{array}{r}-0.240^{*} \\
(0.136)\end{array}$ \\
\hline Negative error values & & & & & & & $\begin{array}{c}0.088^{* *} \\
(0.045)\end{array}$ & $\begin{array}{c}-0.004 \\
(0.079)\end{array}$ \\
\hline Time since last bought car & $\begin{array}{l}0.011^{* * *} \\
(0.000)\end{array}$ & $\begin{array}{l}0.008^{* * *} \\
(0.001)\end{array}$ & $\begin{array}{l}0.011^{* * *} \\
(0.000)\end{array}$ & $\begin{array}{l}0.008^{* * *} \\
(0.001)\end{array}$ & $\begin{array}{l}0.011^{* * *} \\
(0.000)\end{array}$ & $\begin{array}{l}0.008^{* * *} \\
(0.001)\end{array}$ & $\begin{array}{l}0.011^{* * *} \\
(0.000)\end{array}$ & $\begin{array}{l}0.008^{* * *} \\
(0.001)\end{array}$ \\
\hline College education & $\begin{array}{c}-0.142^{* * *} \\
(0.042)\end{array}$ & $\begin{array}{r}-0.131^{*} \\
(0.073)\end{array}$ & $\begin{array}{c}-0.143^{* * *} \\
(0.042)\end{array}$ & $\begin{array}{r}-0.136^{*} \\
(0.073)\end{array}$ & $\begin{array}{c}-0.145^{* * *} \\
(0.042)\end{array}$ & $\begin{array}{r}-0.125^{*} \\
(0.073)\end{array}$ & $\begin{array}{c}-0.143^{* * *} \\
(0.042)\end{array}$ & $\begin{array}{r}-0.129^{*} \\
(0.073)\end{array}$ \\
\hline Partner in household & $\begin{array}{c}-0.009 \\
(0.047)\end{array}$ & $\begin{array}{c}-0.026 \\
(0.077)\end{array}$ & $\begin{array}{c}-0.008 \\
(0.047)\end{array}$ & $\begin{array}{c}-0.025 \\
(0.077)\end{array}$ & $\begin{array}{c}-0.008 \\
(0.047)\end{array}$ & $\begin{array}{c}-0.029 \\
(0.076)\end{array}$ & $\begin{array}{c}-0.008 \\
(0.047)\end{array}$ & $\begin{array}{c}-0.027 \\
(0.076)\end{array}$ \\
\hline Female & $\begin{array}{c}-0.239^{* * *} \\
(0.036)\end{array}$ & $\begin{array}{c}0.005 \\
(0.061)\end{array}$ & $\begin{array}{c}-0.240^{* * *} \\
(0.036)\end{array}$ & $\begin{array}{c}0.005 \\
(0.061)\end{array}$ & $\begin{array}{c}-0.236^{* * *} \\
(0.036)\end{array}$ & $\begin{array}{c}0.006 \\
(0.060)\end{array}$ & $\begin{array}{c}-0.235^{* * *} \\
(0.036)\end{array}$ & $\begin{array}{c}0.005 \\
(0.060)\end{array}$ \\
\hline Age $31-40$ & $\begin{array}{c}-0.179^{* * *} \\
(0.051)\end{array}$ & $\begin{array}{c}-0.011 \\
(0.121)\end{array}$ & $\begin{array}{c}-0.180^{* * * *} \\
(0.051)\end{array}$ & $\begin{array}{c}-0.008 \\
(0.121)\end{array}$ & $\begin{array}{c}-0.173^{* * *} \\
(0.051)\end{array}$ & $\begin{array}{c}-0.006 \\
(0.122)\end{array}$ & $\begin{array}{c}-0.171^{* * *} \\
(0.051)\end{array}$ & $\begin{array}{c}-0.007 \\
(0.122)\end{array}$ \\
\hline Age 41-50 & $\begin{array}{c}-0.301^{* * *} \\
(0.055)\end{array}$ & $\begin{array}{c}0.087 \\
(0.118)\end{array}$ & $\begin{array}{c}-0.302^{* * *} \\
(0.055)\end{array}$ & $\begin{array}{c}0.093 \\
(0.118)\end{array}$ & $\begin{array}{c}-0.291^{* * *} \\
(0.055)\end{array}$ & $\begin{array}{c}0.093 \\
(0.119)\end{array}$ & $\begin{array}{c}-0.290^{* * * *} \\
(0.055)\end{array}$ & $\begin{array}{c}0.092 \\
(0.119)\end{array}$ \\
\hline Age 51-60 & $\begin{array}{c}-0.421^{* * *} \\
(0.058)\end{array}$ & $\begin{array}{c}0.177 \\
(0.117)\end{array}$ & $\begin{array}{c}-0.421^{* * *} \\
(0.058)\end{array}$ & $\begin{array}{c}0.185 \\
(0.117)\end{array}$ & $\begin{array}{c}-0.410^{* * *} \\
(0.058)\end{array}$ & $\begin{array}{c}0.185 \\
(0.118)\end{array}$ & $\begin{array}{c}-0.409^{* * *} \\
(0.058)\end{array}$ & $\begin{array}{c}0.182 \\
(0.118)\end{array}$ \\
\hline Age 61 and older & $\begin{array}{c}-0.576^{* * *} \\
(0.082)\end{array}$ & $\begin{array}{c}0.116 \\
(0.137)\end{array}$ & $\begin{array}{c}-0.579^{* * *} \\
(0.082)\end{array}$ & $\begin{array}{c}0.120 \\
(0.138)\end{array}$ & $\begin{array}{c}-0.572^{* * *} \\
(0.082)\end{array}$ & $\begin{array}{c}0.123 \\
(0.138)\end{array}$ & $\begin{array}{c}-0.570^{* * * *} \\
(0.082)\end{array}$ & $\begin{array}{c}0.120 \\
(0.138)\end{array}$ \\
\hline High urbanization & $\begin{array}{c}0.095 \\
(0.058)\end{array}$ & $\begin{array}{c}0.220^{* *} \\
(0.112)\end{array}$ & $\begin{array}{c}0.096 \\
(0.059)\end{array}$ & $\begin{array}{c}0.224^{* *} \\
(0.112)\end{array}$ & $\begin{array}{c}0.097^{*} \\
(0.058)\end{array}$ & $\begin{array}{c}0.217^{*} \\
(0.112)\end{array}$ & $\begin{array}{c}0.096 \\
(0.058)\end{array}$ & $\begin{array}{c}0.218^{*} \\
(0.112)\end{array}$ \\
\hline Moderate urbanization & $\begin{array}{c}0.156^{* *} \\
(0.062)\end{array}$ & $\begin{array}{c}0.280^{* *} \\
(0.118)\end{array}$ & $\begin{array}{l}0.157^{* *} \\
(0.062)\end{array}$ & $\begin{array}{c}0.280^{* *} \\
(0.118)\end{array}$ & $\begin{array}{l}0.156^{* *} \\
(0.062)\end{array}$ & $\begin{array}{l}0.278^{* *} \\
(0.118)\end{array}$ & $\begin{array}{c}0.156^{* *} \\
(0.062)\end{array}$ & $\begin{array}{l}0.280^{* *} \\
(0.118)\end{array}$ \\
\hline Low urbanization & $\begin{array}{l}0.218^{* * *} \\
(0.061)\end{array}$ & $\begin{array}{c}0.073 \\
(0.125)\end{array}$ & $\begin{array}{l}0.219^{* * * *} \\
(0.061)\end{array}$ & $\begin{array}{c}0.073 \\
(0.125)\end{array}$ & $\begin{array}{l}0.220^{* * * *} \\
(0.061)\end{array}$ & $\begin{array}{c}0.068 \\
(0.125)\end{array}$ & $\begin{array}{l}0.220^{* * *} \\
(0.061)\end{array}$ & $\begin{array}{c}0.070 \\
(0.125)\end{array}$ \\
\hline Very low urbanization & $\begin{array}{l}0.274^{* * *} \\
(0.069)\end{array}$ & $\begin{array}{c}0.142 \\
(0.132)\end{array}$ & $\begin{array}{l}0.275^{* * *} \\
(0.069)\end{array}$ & $\begin{array}{c}0.143 \\
(0.132)\end{array}$ & $\begin{array}{l}0.275^{* * *} \\
(0.069)\end{array}$ & $\begin{array}{c}0.144 \\
(0.132)\end{array}$ & $\begin{array}{l}0.275^{* * *} \\
(0.069)\end{array}$ & $\begin{array}{c}0.144 \\
(0.132)\end{array}$ \\
\hline Number of household members & $\begin{array}{c}0.036^{* *} \\
(0.015)\end{array}$ & $\begin{array}{c}-0.123^{* * *} \\
(0.029)\end{array}$ & $\begin{array}{c}0.036^{* *} \\
(0.015)\end{array}$ & $\begin{array}{c}-0.123^{* * *} \\
(0.029)\end{array}$ & $\begin{array}{c}0.037^{* *} \\
(0.015)\end{array}$ & $\begin{array}{c}-0.124^{* * *} \\
(0.029)\end{array}$ & $\begin{array}{c}0.036^{* *} \\
(0.015)\end{array}$ & $\begin{array}{c}-0.123^{* * *} \\
(0.029)\end{array}$ \\
\hline Main earner in household & $\begin{array}{c}-0.138^{* * *} \\
(0.037)\end{array}$ & $\begin{array}{r}-0.118^{*} \\
(0.065)\end{array}$ & $\begin{array}{c}-0.139^{* * *} \\
(0.037)\end{array}$ & $\begin{array}{r}-0.116^{*} \\
(0.065)\end{array}$ & $\begin{array}{c}-0.138^{* * *} \\
(0.037)\end{array}$ & $\begin{array}{r}-0.124^{*} \\
(0.065)\end{array}$ & $\begin{array}{c}-0.141^{* * *} \\
(0.037)\end{array}$ & $\begin{array}{r}-0.122^{*} \\
(0.065)\end{array}$ \\
\hline $\ln$ (household income) & $\begin{array}{c}-0.061 \\
(0.048)\end{array}$ & $\begin{array}{l}0.488^{* * *} \\
(0.085)\end{array}$ & $\begin{array}{c}-0.062 \\
(0.048)\end{array}$ & $\begin{array}{l}0.482^{* * *} \\
(0.085)\end{array}$ & $\begin{array}{c}-0.065 \\
(0.048)\end{array}$ & $\begin{array}{l}0.503^{* * *} \\
(0.083)\end{array}$ & $\begin{array}{c}-0.060 \\
(0.048)\end{array}$ & $\begin{array}{l}0.497^{* * *} \\
(0.084)\end{array}$ \\
\hline ihs(net worth) & $\begin{array}{c}-0.006^{* * *} \\
(0.002)\end{array}$ & $\begin{array}{c}0.005 \\
(0.003)\end{array}$ & $\begin{array}{c}-0.006^{* * *} \\
(0.002)\end{array}$ & $\begin{array}{c}0.005 \\
(0.003)\end{array}$ & $\begin{array}{c}-0.006^{* * *} \\
(0.002)\end{array}$ & $\begin{array}{c}0.005 \\
(0.003)\end{array}$ & $\begin{array}{c}-0.006^{* * *} \\
(0.002)\end{array}$ & $\begin{array}{c}0.005 \\
(0.003)\end{array}$ \\
\hline Local unemployment & $\begin{array}{c}-0.006 \\
(0.020) \\
\end{array}$ & $\begin{array}{c}0.008 \\
(0.035) \\
\end{array}$ & $\begin{array}{c}-0.006 \\
(0.020) \\
\end{array}$ & $\begin{array}{c}0.008 \\
(0.035) \\
\end{array}$ & $\begin{array}{c}-0.006 \\
(0.020) \\
\end{array}$ & $\begin{array}{c}0.006 \\
(0.035) \\
\end{array}$ & $\begin{array}{c}-0.006 \\
(0.020) \\
\end{array}$ & $\begin{array}{c}0.007 \\
(0.035) \\
\end{array}$ \\
\hline Mean dependent variable & 0.087 & 0.019 & 0.087 & 0.019 & 0.087 & 0.019 & 0.087 & 0.019 \\
\hline $\mathrm{N}$ households & 6,046 & 5,970 & 6,046 & 5,970 & 6,046 & 5,970 & 6,046 & 5,970 \\
\hline $\mathrm{N}$ observations & 18,858 & 18,268 & 18,858 & 18,268 & 18,858 & 18,268 & 18,858 & 18,268 \\
\hline
\end{tabular}

All models are estimated with Probit and also include a set of time fixed effects and dummies for the survey used. Marginal effects averaged over the sample are reported. Outcomes are measured in the 12 months after the job loss expectations are elicited. The reference category for age is 'Age 30 and younger', 'Very high urbanization' for area density, and 'Probability job loss [0-20]' for the job loss expectations. Variables 'Job loss expectation', 'Expectation error', 'Positive error values', and 'Negative error values' are divided by a 100 to increase readability. In addition, 'Negative error values' are transformed to take on values on the positive range. $* / * * / * * *$ correspond to $10 \% / 5 \% / 1 \%$ significance level. 
However, it is this group of workers who acquire cars with lower value (approximately 0.38 percent less for a one percentage point increase in positive error values).

In Table 4 we further investigate the relationship between job loss expectations and car acquisitions by distinguishing old cars and new cars. Old or second-hand cars are identified in the data as cars with at least one previous owner. For new cars, the acquirer is the first owner. All columns report marginal effects after Probit regressions, averaged over the sample. Comparing columns (1) through (4), we find suggestive evidence for substitution effects. An increase in job loss expectations is associated with a lower propensity to buy a new car (column (2)), and a higher probability to acquire a second-hand car (though not statistically significant). In relative terms the marginal effect of job loss expectations on the probability of acquiring a new car is quite sizable. A one percentage point increase in job loss expectations is associated with a 0.283 percentage point decrease in the probability of acquiring a new car, on an unconditional mean of $1.9 \%$. Comparing the grouping of job loss expectations in five categories in columns (3)-(4) shows all positive signs in column (3), and all negative signs in column (4), though only one in each column is statistically significant at 5\%. Looking at the expectation errors again reveals an asymmetric pattern. It is the negative errors that are associated with smaller propensities to acquire a secondhand car, where it is the positive error values that are associated with smaller probabilities to buy a new car.

Taken together, higher job loss expectations are associated with a lower car value (conditional on acquiring a car), as well as a lower propensity to buy a new car. Moreover we find some evidence for a higher propensity to substitute to a second-hand car. This downsizing behavior is suggestive of a form of precautionary behavior, where workers with higher job loss expectations substitute away from new and more expensive vehicles.

\subsection{Household Savings}

Using the administrative data on household assets allows us to investigate more directly precautionary behavior in the area of household savings. In Table 5 the dependent variable is the first difference of balances of savings, stock value and the sum of the two,the difference of financial wealth. Administrative wealth data is only available at the household level, which is why we focus on job loss expectations of the main earner in the household (measured by annual wage income prior to job loss expectations). In all regressions we control for year fixed effects, net worth of a household, and a dummy for home-ownership. In Table 5 higher job loss expectations are associated with more savings, a decrease in the flow of stocks, and a net increase in financial wealth. ${ }^{12}$, In column (1) a one percentage point increase in job loss expectations is associated with a 7.9 euro increase in savings, which is modest relative to an unconditional average savings flow of 417.8 euro. Higher job loss expectations are associated with lower flows of stock value, though not statistically significant in column (2). Comparing columns (4)-(6) shows some suggestive

\footnotetext{
${ }^{12}$ We also experimented with the change in the share of risky assets, but the unconditional share of risky assets is zero for $90 \%$ of the observations.
} 
evidence of patterns of substitution. Lower values of job loss expectations are relatively more associated with a decrease in stock flows than savings. At upper intermediate values (61-80\%) are associated with an increase in both savings and stock flows, resulting in a net increase in financial wealth. Both findings, the increase in savings and the decrease of risky assets are in line with what Basten, Fagereng and Telle (2016) find for a sample of actual unemployed in Norway. They report that workers who would become unemployed increase financial wealth in the years prior to unemployment, by increasing safe assets and decreasing risky assets. Our contribution is that this behavior is already reflected in the job loss expectations of households.

The increase in savings flows and financial wealth is also reflected in the balances at the end of the year. In Table 6 we report the relationship between job loss expectations and balances at the end of the year. Due to the timing when job loss expectations are elicited, there are around 6 to 8 months between the time when most job loss expectations are elicited and the end of the year when financial balances are measured. We find that higher job loss expectations are positively correlated with higher savings balances. For stock balances there is an interesting pattern - lower job loss probabilities are associated with lower stock values (column (5)), but higher job loss probabilities with larger stock balances. The implication is that workers with job loss expectations in the range of [81-100] hold more financial wealth in both safe and risky assets. This finding can be reconciled with the results of the flows in Table 5 by acknowledging that flows are calculated for households with different levels of risky assets at the beginning of the year ${ }^{13}$

One potential reason for our finding of a relatively modest savings response to job loss expectations is that replacement rates in case of unemployment insurance are quite generous. Conditional on being entitled to unemployment benefits, the replacement rate is around $70-75 \%$ of previous earnings. The relative drop in household income is even smaller when the progressive income tax system is taken into account, or in case of a working spouse. A second explanation is that from Subsection 4.1 it is clear that half of all workers with a job loss do not experience an unemployment spell (though there still might be a decrease in income after a transition to another firm). Note that our results cannot be interpreted directly as a consumption (spending) response. For example, households could have some growth in household income and keep consumption constant. In that sense we cannot compare our results directly to studies that find a decrease in consumption in the year before actual job loss as in Gruber (1997); Hendren (2017).

\footnotetext{
${ }^{13}$ Also, we do not explicitly model the extensive margin for holding risky assets. We experimented with job loss expectations and stock ownership, but found little correlation.
} 
Table 5: Job Loss Expectations and Household Savings (Flows)

\begin{tabular}{|c|c|c|c|c|c|c|}
\hline & $\begin{array}{l}\text { Savings } \\
(1)\end{array}$ & $\begin{array}{l}\text { Stocks } \\
(2)\end{array}$ & $\begin{array}{l}\text { Financial Wealth } \\
(3)\end{array}$ & $\begin{array}{l}\text { Savings } \\
(4)\end{array}$ & $\begin{array}{l}\text { Stocks } \\
(5)\end{array}$ & $\begin{array}{c}\text { Financial Wealth } \\
(6)\end{array}$ \\
\hline Job loss expectation & $\begin{array}{l}7.969^{* * *} \\
(2.913)\end{array}$ & $\begin{array}{c}-0.047 \\
(0.784)\end{array}$ & $\begin{array}{l}6.763^{* *} \\
(3.052)\end{array}$ & & & \\
\hline Probability job loss [21-40] & & & & $\begin{array}{c}109.995 \\
(223.006)\end{array}$ & $\begin{array}{c}-147.614^{* *} \\
(67.665)\end{array}$ & $\begin{array}{l}-28.990 \\
(247.511)\end{array}$ \\
\hline Probability job loss [41-60] & & & & $\begin{array}{l}497.650^{* *} \\
(204.627)\end{array}$ & $\begin{array}{l}-4.789 \\
(54.234)\end{array}$ & $\begin{array}{l}528.219^{* *} \\
(214.462)\end{array}$ \\
\hline Probability job loss [61-80] & & & & $\begin{array}{c}567.693 \\
(435.596)\end{array}$ & $\begin{array}{c}126.766 \\
(118.038)\end{array}$ & $\begin{array}{r}736.117^{*} \\
(435.514)\end{array}$ \\
\hline Probability job loss [81-100] & & & & $\begin{array}{c}581.307 \\
(408.538)\end{array}$ & $\begin{array}{l}-55.961 \\
(103.217)\end{array}$ & $\begin{array}{c}180.712 \\
(438.424)\end{array}$ \\
\hline College education & $\begin{array}{r}-332.675^{*} \\
(183.564)\end{array}$ & $\begin{array}{l}177.766^{* * *} \\
(59.138)\end{array}$ & $\begin{array}{c}-160.078 \\
(207.179)\end{array}$ & $\begin{array}{r}-325.125^{*} \\
(183.779)\end{array}$ & $\begin{array}{l}178.714^{* * *} \\
(59.039)\end{array}$ & $\begin{array}{c}-149.263 \\
(207.259)\end{array}$ \\
\hline Partner in household & $\begin{array}{c}-260.508 \\
(177.199)\end{array}$ & $\begin{array}{c}-116.256^{* *} \\
(55.163)\end{array}$ & $\begin{array}{r}-396.635^{*} \\
(203.813)\end{array}$ & $\begin{array}{c}-263.017 \\
(177.320)\end{array}$ & $\begin{array}{c}-118.585^{* *} \\
(55.165)\end{array}$ & $\begin{array}{c}-402.678^{* *} \\
(203.809)\end{array}$ \\
\hline Female & $\begin{array}{r}-236.419^{*} \\
(134.094)\end{array}$ & $\begin{array}{c}-68.917 \\
(43.772)\end{array}$ & $\begin{array}{c}-350.880^{* *} \\
(152.510)\end{array}$ & $\begin{array}{r}-240.885^{*} \\
(134.374)\end{array}$ & $\begin{array}{c}-70.172 \\
(43.767)\end{array}$ & $\begin{array}{c}-352.333^{* *} \\
(152.868)\end{array}$ \\
\hline Age $31-40$ & $\begin{array}{c}-344.196 \\
(219.869)\end{array}$ & $\begin{array}{c}17.352 \\
(49.896)\end{array}$ & $\begin{array}{c}-297.822 \\
(239.234)\end{array}$ & $\begin{array}{c}-347.231 \\
(219.963)\end{array}$ & $\begin{array}{c}18.211 \\
(49.920)\end{array}$ & $\begin{array}{c}-304.257 \\
(239.480)\end{array}$ \\
\hline Age $41-50$ & $\begin{array}{c}-627.995^{* * *} \\
(229.709)\end{array}$ & $\begin{array}{c}-24.763 \\
(59.107)\end{array}$ & $\begin{array}{c}-674.609^{* * *} \\
(252.371)\end{array}$ & $\begin{array}{c}-633.500^{* * *} \\
(230.023)\end{array}$ & $\begin{array}{c}-23.938 \\
(59.121)\end{array}$ & $\begin{array}{c}-684.542^{* * *} \\
(252.720)\end{array}$ \\
\hline Age 51-60 & $\begin{array}{c}-858.592^{* * *} \\
(240.593)\end{array}$ & $\begin{array}{c}9.831 \\
(57.925)\end{array}$ & $\begin{array}{c}-859.782^{* * *} \\
(267.022)\end{array}$ & $\begin{array}{c}-871.292^{* * *} \\
(240.840)\end{array}$ & $\begin{array}{c}8.502 \\
(57.978)\end{array}$ & $\begin{array}{c}-876.984^{* * *} \\
(267.358)\end{array}$ \\
\hline Age 61 and older & $\begin{array}{c}-967.390^{* * *} \\
(341.931)\end{array}$ & $\begin{array}{c}-27.920 \\
(92.874)\end{array}$ & $\begin{array}{c}-1141.829^{* * *} \\
(367.075)\end{array}$ & $\begin{array}{c}-981.173^{* * *} \\
(341.635)\end{array}$ & $\begin{array}{c}-29.710 \\
(92.708)\end{array}$ & $\begin{array}{c}-1149.913^{* * *} \\
(366.425)\end{array}$ \\
\hline High urbanization & $\begin{array}{c}-210.089 \\
(206.522)\end{array}$ & $\begin{array}{r}-136.296^{*} \\
(70.991)\end{array}$ & $\begin{array}{c}-398.865 \\
(246.746)\end{array}$ & $\begin{array}{c}-212.143 \\
(206.677)\end{array}$ & $\begin{array}{r}-137.822^{*} \\
(70.893)\end{array}$ & $\begin{array}{c}-403.400 \\
(247.004)\end{array}$ \\
\hline Moderate urbanization & $\begin{array}{c}-303.334 \\
(235.175)\end{array}$ & $\begin{array}{c}-88.858 \\
(83.645)\end{array}$ & $\begin{array}{c}-432.136 \\
(274.644)\end{array}$ & $\begin{array}{c}-302.037 \\
(235.844)\end{array}$ & $\begin{array}{c}-92.022 \\
(83.558)\end{array}$ & $\begin{array}{c}-430.132 \\
(275.173)\end{array}$ \\
\hline Low urbanization & $\begin{array}{r}-425.509^{*} \\
(230.348)\end{array}$ & $\begin{array}{c}-160.661^{* *} \\
(79.787)\end{array}$ & $\begin{array}{c}-621.410^{* *} \\
(274.135)\end{array}$ & $\begin{array}{r}-429.101^{*} \\
(230.505)\end{array}$ & $\begin{array}{c}-164.126^{* *} \\
(79.605)\end{array}$ & $\begin{array}{c}-627.879^{* *} \\
(274.335)\end{array}$ \\
\hline Very low urbanization & $\begin{array}{c}-319.932 \\
(301.328)\end{array}$ & $\begin{array}{c}-224.878^{* *} \\
(95.388)\end{array}$ & $\begin{array}{r}-594.580^{*} \\
(359.591)\end{array}$ & $\begin{array}{c}-322.793 \\
(301.546)\end{array}$ & $\begin{array}{c}-226.995^{* *} \\
(95.340)\end{array}$ & $\begin{array}{r}-601.204^{*} \\
(359.943)\end{array}$ \\
\hline Number of household members & $\begin{array}{c}-504.405^{* * *} \\
(74.794)\end{array}$ & $\begin{array}{r}-46.015^{*} \\
(25.280)\end{array}$ & $\begin{array}{c}-557.173^{* * *} \\
(83.737)\end{array}$ & $\begin{array}{c}-503.898^{* * *} \\
(74.752)\end{array}$ & $\begin{array}{r}-44.333^{*} \\
(25.243)\end{array}$ & $\begin{array}{c}-555.677^{* * *} \\
(83.686)\end{array}$ \\
\hline $\ln$ (household income) & $\begin{array}{l}2153.754^{* * *} \\
(250.895)\end{array}$ & $\begin{array}{l}203.924^{* * *} \\
(76.252)\end{array}$ & $\begin{array}{l}2319.872^{* * *} \\
(283.737)\end{array}$ & $\begin{array}{l}2159.383^{* * *} \\
(251.612)\end{array}$ & $\begin{array}{l}204.090^{* * *} \\
(76.229)\end{array}$ & $\begin{array}{l}2332.552^{* * *} \\
(283.960)\end{array}$ \\
\hline ihs(net worth) & $\begin{array}{l}38.952^{* * *} \\
(6.009)\end{array}$ & $\begin{array}{l}9.522^{* * *} \\
(1.914)\end{array}$ & $\begin{array}{l}55.084^{* * *} \\
(6.799)\end{array}$ & $\begin{array}{l}39.008^{* * *} \\
(6.011)\end{array}$ & $\begin{array}{l}9.452^{* * *} \\
(1.913)\end{array}$ & $\begin{array}{l}54.946^{* * *} \\
(6.801)\end{array}$ \\
\hline Home owner & $\begin{array}{c}-560.503^{* * *} \\
(171.552)\end{array}$ & $\begin{array}{c}41.932 \\
(40.894)\end{array}$ & $\begin{array}{c}-557.544^{* * *} \\
(196.670)\end{array}$ & $\begin{array}{c}-557.931^{* * *} \\
(171.344)\end{array}$ & $\begin{array}{c}42.285 \\
(40.931)\end{array}$ & $\begin{array}{c}-553.175^{* * *} \\
(196.420)\end{array}$ \\
\hline Local unemployment & $\begin{array}{l}-5.412 \\
(58.478)\end{array}$ & $\begin{array}{c}-15.441 \\
(19.767)\end{array}$ & $\begin{array}{c}-38.342 \\
(67.333)\end{array}$ & $\begin{array}{l}-5.604 \\
(58.467)\end{array}$ & $\begin{array}{c}-15.938 \\
(19.733)\end{array}$ & $\begin{array}{c}-37.898 \\
(67.351)\end{array}$ \\
\hline Constant & $\begin{array}{c}-20765.384^{* * *} \\
(2347.569)\end{array}$ & $\begin{array}{c}-1934.006^{* * *} \\
(728.001)\end{array}$ & $\begin{array}{c}-22131.006^{* * *} \\
(2651.491)\end{array}$ & $\begin{array}{c}-20778.783^{* * *} \\
(2350.375)\end{array}$ & $\begin{array}{c}-1924.000^{* * *} \\
(726.479)\end{array}$ & $\begin{array}{c}-22217.607^{* * *} \\
(2649.203)\end{array}$ \\
\hline Adjusted R-squared & 0.024 & 0.021 & 0.030 & 0.024 & 0.021 & 0.030 \\
\hline Mean dependent variable & 417.800 & 85.501 & 518.427 & 417.800 & 85.501 & 518.427 \\
\hline $\mathrm{N}$ households & 4,347 & 4,347 & 4,347 & 4,347 & 4,347 & 4,347 \\
\hline N observations & 13,033 & 13,033 & 13,033 & 13,033 & 13,033 & 13,033 \\
\hline
\end{tabular}

All models are estimated with OLS and also include a set of year fixed effects and dummies for the survey used. The sample is restricted to one observation for each household, job loss expectations of the main earner are used. Outcomes are measured in the year that job loss expectations are elicited. The reference category for age is 'Age 30 and younger', 'Very high urbanization' for area density, and 'Probability job loss [0-20]' for the job loss expectations. Robust standard errors (in parentheses) are clustered at the household level.

*/**/*** correspond to $10 \% / 5 \% / 1 \%$ significance level. 
Table 6: Job Loss Expectations and Household Finances (Levels)

\begin{tabular}{|c|c|c|c|c|c|c|}
\hline & $\begin{array}{l}\text { Savings } \\
\text { (1) }\end{array}$ & $\begin{array}{l}\text { Stocks } \\
(2)\end{array}$ & $\begin{array}{c}\text { Financial Wealth } \\
\text { (3) }\end{array}$ & $\begin{array}{l}\text { Savings } \\
(4)\end{array}$ & $\begin{array}{l}\text { Stocks } \\
(5)\end{array}$ & $\begin{array}{c}\text { Financial Wealth } \\
(6)\end{array}$ \\
\hline Job loss expectation & $\begin{array}{l}0.048^{* * *} \\
(0.014)\end{array}$ & $\begin{array}{c}0.009 \\
(0.007)\end{array}$ & $\begin{array}{l}0.056^{* * *} \\
(0.019)\end{array}$ & & & \\
\hline Probability job loss [21-40] & & & & $\begin{array}{l}2.388^{* *} \\
(0.972)\end{array}$ & $\begin{array}{r}-0.755^{*} \\
(0.400)\end{array}$ & $\begin{array}{c}1.542 \\
(1.207)\end{array}$ \\
\hline Probability job loss [41-60] & & & & $\begin{array}{l}2.333^{* *} \\
(1.009)\end{array}$ & $\begin{array}{c}-0.084 \\
(0.424)\end{array}$ & $\begin{array}{r}2.263^{*} \\
(1.255)\end{array}$ \\
\hline Probability job loss [61-80] & & & & $\begin{array}{c}1.878 \\
(1.613)\end{array}$ & $\begin{array}{c}0.040 \\
(0.704)\end{array}$ & $\begin{array}{c}1.917 \\
(2.010)\end{array}$ \\
\hline Probability job loss [81-100] & & & & $\begin{array}{l}3.839^{* *} \\
(1.820)\end{array}$ & $\begin{array}{l}1.642^{*} \\
(0.996)\end{array}$ & $\begin{array}{l}5.271^{* *} \\
(2.481)\end{array}$ \\
\hline College education & $\begin{array}{l}4.011^{* * *} \\
(1.185)\end{array}$ & $\begin{array}{l}2.658^{* * *} \\
(0.648)\end{array}$ & $\begin{array}{l}7.022^{* * *} \\
(1.680)\end{array}$ & $\begin{array}{l}4.020^{* * *} \\
(1.188)\end{array}$ & $\begin{array}{l}2.648^{* * * *} \\
(0.648)\end{array}$ & $\begin{array}{l}7.024^{* * *} \\
(1.683)\end{array}$ \\
\hline Partner in household & $\begin{array}{c}0.301 \\
(1.141)\end{array}$ & $\begin{array}{c}-1.367^{* *} \\
(0.537)\end{array}$ & $\begin{array}{c}-1.470 \\
(1.598)\end{array}$ & $\begin{array}{c}0.322 \\
(1.140)\end{array}$ & $\begin{array}{c}-1.366^{* *} \\
(0.537)\end{array}$ & $\begin{array}{c}-1.449 \\
(1.597)\end{array}$ \\
\hline Female & $\begin{array}{c}-0.179 \\
(0.909)\end{array}$ & $\begin{array}{l}-0.656 \\
(0.457)\end{array}$ & $\begin{array}{l}-1.086 \\
(1.236)\end{array}$ & $\begin{array}{c}-0.182 \\
(0.907)\end{array}$ & $\begin{array}{c}-0.683 \\
(0.456)\end{array}$ & $\begin{array}{l}-1.115 \\
(1.234)\end{array}$ \\
\hline Age $31-40$ & $\begin{array}{r}-1.296 \\
(0.880)\end{array}$ & $\begin{array}{l}0.336 \\
(0.410)\end{array}$ & $\begin{array}{c}-0.860 \\
(1.214)\end{array}$ & $\begin{array}{c}-1.308 \\
(0.880)\end{array}$ & $\begin{array}{l}0.365 \\
(0.411)\end{array}$ & $\begin{array}{l}-0.845 \\
(1.214)\end{array}$ \\
\hline Age $41-50$ & $\begin{array}{l}0.100 \\
(1.087)\end{array}$ & $\begin{array}{l}1.771^{* * *} \\
(0.445)\end{array}$ & $\begin{array}{c}1.701 \\
(1.392)\end{array}$ & $\begin{array}{l}0.087 \\
(1.087)\end{array}$ & $\begin{array}{l}1.810^{* * *} \\
(0.446)\end{array}$ & $\begin{array}{l}1.725 \\
(1.392)\end{array}$ \\
\hline Age 51-60 & $\begin{array}{l}1.565 \\
(1.168)\end{array}$ & $\begin{array}{l}2.464^{* * *} \\
(0.511)\end{array}$ & $\begin{array}{l}4.137^{* * *} \\
(1.528)\end{array}$ & $\begin{array}{c}1.542 \\
(1.166)\end{array}$ & $\begin{array}{l}2.479^{* * *} \\
(0.511)\end{array}$ & $\begin{array}{l}4.127^{* * *} \\
(1.527)\end{array}$ \\
\hline Age 61 and older & $\begin{array}{l}5.761^{* * *} \\
(1.771)\end{array}$ & $\begin{array}{l}3.498^{* * *} \\
(0.896)\end{array}$ & $\begin{array}{l}10.060^{* * *} \\
(2.480)\end{array}$ & $\begin{array}{l}5.714^{* * *} \\
(1.765)\end{array}$ & $\begin{array}{l}3.446^{* * *} \\
(0.890)\end{array}$ & $\begin{array}{l}9.963^{* * *} \\
(2.470)\end{array}$ \\
\hline High urbanization & $\begin{array}{l}-3.889^{* * *} \\
(1.426)\end{array}$ & $\begin{array}{r}-1.396^{*} \\
(0.755)\end{array}$ & $\begin{array}{l}-5.190^{* * *} \\
(2.002)\end{array}$ & $\begin{array}{c}-3.877^{* * *} \\
(1.426)\end{array}$ & $\begin{array}{r}-1.393^{*} \\
(0.755)\end{array}$ & $\begin{array}{c}-5.176^{* * *} \\
(2.003)\end{array}$ \\
\hline Moderate urbanization & $\begin{array}{c}-3.200^{* *} \\
(1.587)\end{array}$ & $\begin{array}{l}-0.418 \\
(0.875)\end{array}$ & $\begin{array}{c}-3.151 \\
(2.272)\end{array}$ & $\begin{array}{c}-3.158^{* *} \\
(1.590)\end{array}$ & $\begin{array}{c}-0.453 \\
(0.875)\end{array}$ & $\begin{array}{c}-3.145 \\
(2.277)\end{array}$ \\
\hline Low urbanization & $\begin{array}{c}-3.265^{* *} \\
(1.596)\end{array}$ & $\begin{array}{c}-0.307 \\
(0.866)\end{array}$ & $\begin{array}{c}-3.431 \\
(2.272)\end{array}$ & $\begin{array}{c}-3.235^{* *} \\
(1.596)\end{array}$ & $\begin{array}{c}-0.325 \\
(0.865)\end{array}$ & $\begin{array}{c}-3.420 \\
(2.273)\end{array}$ \\
\hline Very low urbanization & $\begin{array}{l}-2.456 \\
(1.917)\end{array}$ & $\begin{array}{l}-0.825 \\
(1.021)\end{array}$ & $\begin{array}{c}-3.627 \\
(2.664)\end{array}$ & $\begin{array}{c}-2.445 \\
(1.918)\end{array}$ & $\begin{array}{c}-0.825 \\
(1.021)\end{array}$ & $\begin{array}{c}-3.617 \\
(2.666)\end{array}$ \\
\hline Number of household members & $\begin{array}{c}-1.826^{* * *} \\
(0.463)\end{array}$ & $\begin{array}{r}-0.463^{*} \\
(0.246)\end{array}$ & $\begin{array}{c}-2.531^{* * *} \\
(0.671)\end{array}$ & $\begin{array}{c}-1.840^{* * *} \\
(0.463)\end{array}$ & $\begin{array}{r}-0.451^{*} \\
(0.246)\end{array}$ & $\begin{array}{c}-2.533^{* * *} \\
(0.671)\end{array}$ \\
\hline $\ln$ (household income) & $\begin{array}{l}22.462^{* * *} \\
(1.574)\end{array}$ & $\begin{array}{l}6.424^{* * *} \\
(0.762)\end{array}$ & $\begin{array}{l}31.346^{* * *} \\
(2.252)\end{array}$ & $\begin{array}{l}22.446^{* * *} \\
(1.573)\end{array}$ & $\begin{array}{l}6.372^{* * *} \\
(0.756)\end{array}$ & $\begin{array}{l}31.283^{* * *} \\
(2.248)\end{array}$ \\
\hline ihs(net worth) & $\begin{array}{l}0.945^{* * *} \\
(0.031)\end{array}$ & $\begin{array}{l}0.193^{* * *} \\
(0.017)\end{array}$ & $\begin{array}{l}1.193^{* * *} \\
(0.044)\end{array}$ & $\begin{array}{l}0.946^{* * *} \\
(0.031)\end{array}$ & $\begin{array}{l}0.194^{* * *} \\
(0.017)\end{array}$ & $\begin{array}{l}1.195^{* * *} \\
(0.044)\end{array}$ \\
\hline Home owner & $\begin{array}{c}2.057^{*} \\
(1.087)\end{array}$ & $\begin{array}{l}1.180^{* * *} \\
(0.411)\end{array}$ & $\begin{array}{c}2.852^{*} \\
(1.461)\end{array}$ & $\begin{array}{c}2.042^{*} \\
(1.088)\end{array}$ & $\begin{array}{l}1.167^{* * *} \\
(0.412)\end{array}$ & $\begin{array}{c}2.826^{*} \\
(1.463)\end{array}$ \\
\hline Local unemployment & $\begin{array}{c}-0.884^{* *} \\
(0.364)\end{array}$ & $\begin{array}{c}-0.267 \\
(0.194)\end{array}$ & $\begin{array}{c}-1.103^{* *} \\
(0.509)\end{array}$ & $\begin{array}{c}-0.881^{* *} \\
(0.365)\end{array}$ & $\begin{array}{c}-0.274 \\
(0.194)\end{array}$ & $\begin{array}{c}-1.107^{* *} \\
(0.510)\end{array}$ \\
\hline Constant & $\begin{array}{c}-203.272^{* * *} \\
(14.779)\end{array}$ & $\begin{array}{c}-59.720^{* * *} \\
(7.372)\end{array}$ & $\begin{array}{c}-286.561^{* * *} \\
(21.261)\end{array}$ & $\begin{array}{c}-202.927^{* * *} \\
(14.755)\end{array}$ & $\begin{array}{c}-59.038^{* * *} \\
(7.299)\end{array}$ & $\begin{array}{c}-285.586^{* * *} \\
(21.188)\end{array}$ \\
\hline Adjusted R-squared & 0.253 & 0.093 & 0.250 & 0.253 & 0.094 & 0.249 \\
\hline Mean dependent variable & 20.466 & 4.250 & 25.505 & 20.466 & 4.250 & 25.505 \\
\hline $\mathrm{N}$ households & 4,347 & 4,347 & 4,347 & 4,347 & 4,347 & 4,347 \\
\hline $\mathrm{N}$ observations & 13,033 & 13,033 & 13,033 & 13,033 & 13,033 & 13,033 \\
\hline
\end{tabular}

All models are estimated with OLS and also include a set of year fixed effects and dummies for the survey used. The sample is restricted to one observation for each household, job loss expectations of the main earner are used. Outcomes are measured at the end of the calendar that job loss expectations are elicited. The reference category for age is 'Age 30 and younger', 'Very high urbanization' for area density, and 'Probability job loss [0-20]' for the job loss expectations. Robust standard errors (in parentheses) are clustered at the household level.

$* / * * / * * *$ correspond to $10 \% / 5 \% / 1 \%$ significance level. 


\section{Conclusions}

In this study we link survey data with job loss expectations of workers to administrative data on labor market outcomes, as well as car acquisitions and household savings. We find that using administrative data increases the accuracy of job loss expectations, and that job loss expectations are quite informative about future transitions into unemployment and new jobs with different firms. Using administrative data also has some disadvantages: it is difficult to distinguish voluntary from involuntary transitions, except for the case of recipients of unemployment benefits (in which case we would need the assumption that these are all involuntary transitions). We also find that job loss expectations are not correlated with transitions to new jobs within the firm. Both findings could be fruitful areas for development of new survey instruments to complement existing survey questions. With regards to the relationship between job loss expectations and economic outcomes, we find that workers with higher job loss expectations are less likely to acquire new cars, and acquire cars with lower value. These novel findings point to two margins of precautionary behavior, where workers substitute away from new cars to used cars, and downgrade in general. In the context of household savings and financial portfolios we report that households with higher job loss expectations save more, and we find some suggestive evidence that households substitute away from risky assets. These findings are in line with models of precautionary savings behavior due to unemployment risk, and complement existing studies that finds evidence for the actual unemployed (e.g. Basten, Fagereng and Telle $(2016))$.

\section{References}

Basten, Christoph, Andreas Fagereng, and Kjetil Telle. 2016. "Saving and portfolio allocation before and after job loss." Journal of Money, Credit and Banking, 48(2-3): 293324.

Benito, Andrew. 2006. "Does job insecurity affect household consumption?" Oxford Economic Papers, 58(1): 157-181.

Browning, Martin, and Thomas F Crossley. 2009. "Shocks, stocks, and socks: Smoothing consumption over a temporary income loss." Journal of the European Economic Association, 7(6): 1169-1192.

Campbell, David, Alan Carruth, Andrew Dickerson, and Francis Green. 2007. "Job insecurity and wages." The Economic Journal, 117(518): 544-566.

Carroll, Christopher D, and Wendy E Dunn. 1997. "Unemployment expectations, jumping (S, s) triggers, and household balance sheets." NBER macroeconomics annual, 12: $165-217$.

Carroll, Christopher D, Karen E Dynan, and Spencer D Krane. 2003. "Unemployment risk and precautionary wealth: Evidence from households' balance sheets." Review of Economics and Statistics, 85(3): 586-604. 
Crossley, Thomas F, Jochem de Bresser, Liam Delaney, and Joachim Winter. 2017. "Can survey participation alter household saving behaviour?" The Economic Journal, 127(606): 2332-2357.

Curtin, Richard T. 2003. "Unemployment expectations: The impact of private information on income uncertainty." Review of Income and Wealth, 49(4): 539-554.

Dominitz, Jeff. 2001. "Estimation of income expectations models using expectations and realization data." Journal of Econometrics, 102(2): 165-195.

Dominitz, Jeff, and Charles F Manski. 1997. "Using expectations data to study subjective income expectations." Journal of the American statistical Association, 92(439): 855-867.

Gruber, Jonathan. 1997. "The Consumption Smoothing Benefits of Unemployment Insurance." The American Economic Review, 87(1): 192-205.

Hausman, Jerry A, Jason Abrevaya, and Fiona M Scott-Morton. 1998. "Misclassification of the dependent variable in a discrete-response setting." Journal of econometrics, 87(2): 239-269.

Hendren, Nathaniel. 2017. "Knowledge of future job loss and implications for unemployment insurance." American Economic Review, 107(7): 1778-1823.

Jürges, Hendrik. 2007. "Unemployment, life satisfaction and retrospective error." Journal of the Royal Statistical Society: Series A (Statistics in Society), 170(1): 43-61.

Klemm, Marcus. 2012. "Job Security Perceptions and the Saving Behavior of German Households." Ruhr Economic Paper, , (380).

Manski, Charles F, and John D Straub. 2000. "Worker Perceptions of Job Insecurity in the Mid-1990s." Journal of Human Resources, 35(3): 447-79.

Meyer, Bruce D, and Nikolas Mittag. 2017. "Misclassification in binary choice models." Journal of Econometrics, 200(2): 295-311.

Stephens Jr, Melvin. 2004. "Job loss expectations, realizations, and household consumption behavior." Review of Economics and statistics, 86(1): 253-269. 


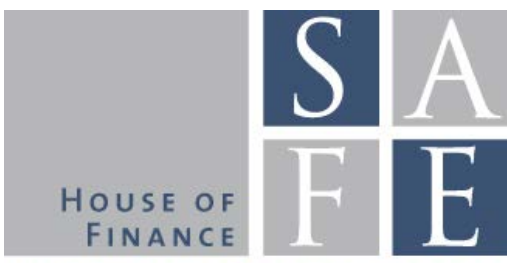

WORKING PAPER SERIES

\section{Recent Issues}

No. 248 Jasmin Gider, Simon N. M.

Schmickler, Christian Westheide

No. 247 Mario Bellia, Loriana Pelizzon, Marti G. Subrahmanyam, Jun Uno, Draya Yuferova

No. 246 Reint Gropp, Felix Noth, Ulrich Schüwer

No. 245 Charline Uhr, Steffen Meyer, Andreas Hackethal

No. 244 Mauro Bernardi, Michele Costola

No. 243 Nicoletta Berardi, Marie Lalanne, Paul Seabright

No. 242 Ester Faia, Vincenzo Pezone

No. 241 Martin Götz

No. 240 Irina Gemmo, Martin Götz

No. 239 Paul Gortner, Baptiste Massenot

No. 238 Joost Driessen, Theo E. Nijman, Zorka Simon

No. 237 Nathanael Vellekoop
High-Frequency Trading and Price Informativeness

Paying for Market Liquidity: Competition and Incentives

What Drives Banks' Geographic Expansion? The Role of Locally Non-Diversifiable Risk

Smoking Hot Portfolios? Self-Control and Investor Decisions

High-Dimensional Sparse Financial Networks through a Regularised Regression Model

Professional Networks and their Coevolution with Executive Careers: Evidence from North America and Europe

Monetary Policy and the Cost of Wage Rigidity: Evidence from the Stock Market

Financial Constraints and Corporate EnvironmentalResponsibility

Life Insurance and Demographic Change: An Empirical Analysis of Surrender Decisions Based on Panel Data

Macroprudential Policy in the Lab

Much Ado About Nothing: A Study of Differential Pricing and Liquidity of Short and Long Term Bonds

Explaining Intra-Monthly Consumption Patterns: The Timing of Income or the Timing of Consumption Commitments? 